Vinícius Guilherme Bion/ Os beneficios por incapacidade e o reconhecimento destes na espécie acidentária pelo poder judiciário de

\title{
OS BENEFÍCIOS POR INCAPACIDADE E O RECONHECIMENTO DESTES NA ESPÉCIE ACIDENTÁRIA PELO PODER JUDICIÁRIO DE SANTA CATARINA
}

\section{THE WELFARE BENEFITS SYSTEM IN SANTA CATARINA: THE JUDICIAL INTERPRETATION}

\author{
VINÍCIUS GUILHERME BION* \\ Faculdades Borges de Mendonça
}

RESUMO: O presente trabalho trata dos benefícios previdenciários por incapacidade (Aposentadoria Por Invalidez, Auxílio-Doença e Auxílio-Acidente) enquanto mecanismos de garantia da Proteção Social do trabalhador e o reconhecimento destes na espécie acidentária, de acordo com decisões proferidas pelo Tribunal de Justiça de Santa Catarina.

PALAVRAS-CHAVE: Proteção Social do Trabalhador; Previdência Social; Benefícios Por Incapacidade; Acidente de Trabalho; Reconhecimento dos Benefícios por Incapacidade na espécie acidentária pelo Poder Judiciário de Santa Catarina

ABSTRACT: The mains purpose of this essay is to explore and to explain the mode that welfare benefit system works under labor law legislation, especially in regards to the social security guarantees and how these legal causals (disabilities causes) are judges by labor courts in Santa Catarina.

KEY WORDS: Social security; disability insurance; welfares system; Judicial interpretation by the Labor courts in Santa Catarina

\section{INTRODUCÃO}

A proteção social do trabalhador pelo Estado - conjunto de medidas de caráter social destinadas ao atendimento das necessidades individuais que uma vez não atendidas repercutirão sobre a sociedade - tem origem relacionada ao desenvolvimento da estrutura estatal.

O Estado contemporâneo possui entre suas funções a proteção social dos indivíduos em relação aos eventos que lhes possam causar dificuldade ou até mesmo impossibilidade de subsistência por conta própria. Dessa forma, para a formação de um sistema de proteção social, partiu-se do assistencialismo para o Seguro Social, e deste para a formação da Seguridade Social, que por sua vez, corresponde a um tripé, cujas bases são os direitos à Saúde, à Assistência Social e à Previdência Social.

Nesse diapasão, a Constituição Federal garantiu legalmente que a Seguridade Social é dever do Estado e direito dos cidadãos, o que faz ampliar a responsabilidade estatal na defesa e garantia dos direitos sociais, a fim de se assegurar a proteção social do trabalhador.

\footnotetext{
* Professor Derecho del Trabajo, Faculdades Borges de Mendonça. Posgrado en Derecho de la Seguridad Social CESUSC. Advogado domiciliado na cidade de Florianópolis. Rua Araújo Figueiredo, n ${ }^{\circ}$ 100, Centro Florianópolis - SC. CEP: 88010-520. Contacto: viniciusbion@hotmail.com

Este trabajo fue recibido el 04 de abril de 2016 y aprobado el 24 de junio de 2016.
} 
A Previdência Social é um direito subjetivo do cidadão em face da sociedade a que pertence, mediante participação através de aportes que garantam recursos suficientes à aplicação da política de segurança social.

Assim, existem três sistemas de regimes previdenciários: a) social-democrático pressupõe a universalidade de cobertura a todos os cidadãos; b) conservador-corporativo, que prioriza o seguro social compulsório voltado à proteção dos riscos sociais e; c) liberal, o qual garante proteção residual, mediante garantia de benefícios que visam combater a pobreza e a manutenção de um patamar mínimo de renda.

No Brasil, a Previdência Social é composta por mais de um regime jurídico, dentre eles, o Regime Geral de Previdência Social, que por sua vez, alcança a maior parte dos trabalhadores e possui natureza contributiva compulsória. A relação jurídica previdenciária deste regime é aquela cujo indivíduo filiado e seus dependentes figuram como credores, ao passo que o Estado atua como devedor.

Em suma, o objetivo da relação jurídica de natureza previdenciária é a entrega da prestação correspondente ao fato ocorrido com o segurado, seja por meio da obrigação de dar (concessão dos benefícios previdenciários) ou da obrigação de fazer (realização de serviços de reabilitação profissional e decorrentes do serviço social).

No que diz respeito aos segurados, os benefícios previdenciários são vários, dentre eles: Aposentadoria Por Invalidez; Aposentadoria Por Idade; Aposentadoria Por Tempo de Contribuição; Aposentadoria Especial; Auxílio-doença; Auxílio-acidente, Salário-família e Salário-maternidade. Já com relação aos dependentes dos segurados, os benefícios são: Pensão por morte e Auxílio-reclusão.

Os benefícios previdenciários que têm como pressuposto a incapacidade laboral objetivam a manutenção da dignidade da pessoa humana para garantir o sustento próprio e de sua família até a recuperação da capacidade profissional.

São benefícios por incapacidade: Aposentadoria por Invalidez - concedida aos segurados que, por doença ou acidente, vierem a ser considerados incapacitados de forma permanente para o exercício de suas atividades profissionais, ou outro tipo de serviço que lhe garanta o sustento próprio; Auxílio-Doença, o qual é devido aos segurados que permanecerem incapacitados para o exercício da atividade profissional por período superior a quinze dias e; Auxílio-Acidente, que por sua vez, consiste no benefício pago ao segurado empregado (exceto doméstico), trabalhador avulso e ao segurado especial, como forma de indenização, após a consolidação de lesões decorrentes de acidente de qualquer natureza em que resultar sequelas que impliquem na redução da capacidade laborativa.

A legislação define o acidente de trabalho como aquele que ocorre pelo exercício do trabalho a serviço da empresa ou não, provocando lesão corporal ou perturbação funcional, permanente ou temporária, que causa a morte, a perda ou a redução da capacidade laboral.

Existem três modalidades de acidente de trabalho: acidente típico (tipo); doenças ocupacionais e acidente por equiparação.

Os benefícios por incapacidade Aposentadoria por Invalidez e Auxílio-doença podem ser concedidos na espécie acidentária, na ocasião em que restar comprovada a correlação entre as patologias incapacitantes acometidas pelo segurado e a atividade profissional desempenhada por ele. Para fins de comprovação dessa relação entre doenças incapacitantes e atividade laboral, se faz necessário caracterizar o nexo de causalidade entre um e outro.

Dessa forma, na esfera judicial, o principal meio de prova utilizado para caracterização do acidente do trabalho é a Comunicação de Acidente de Trabalho - CAT, que nada mais é do que o documento capaz de formalizar a notificação de um acidente do trabalho. 
Nesse contexto, o presente trabalho tem o fim de analisar julgados proferidos pelo Tribunal de Justiça de Santa Catarina no tocante ao reconhecimento dos benefícios por incapacidade em sua benesse acidentária.

\section{DESENVOLVIMENTO}

\subsection{PROTECAOO SOCIAL DO TRABALHADOR}

A proteção social do trabalhador pode ser compreendida como o conjunto de medidas de caráter social destinadas ao atendimento de necessidades individuais que uma vez não atendidas repercutirão sobre a sociedade.

$\mathrm{O}$ direito à proteção social do trabalhador pelo Estado tem origem diretamente relacionada ao desenvolvimento da sua estrutura e da discussão histórica acerca de quais deveriam ser as funções estatais.

Nesse diapasão, até se chegar a um Estado intervencionista, qual seja, realizador dos direitos sociais dos cidadãos, o caminho foi deveras árduo. Isto porque, na formação do Estado Liberal foram interligados fatores determinantes ao aparecimento das Constituições, como por exemplo, a influência do jusnaturalismo, que defendia a superioridade do individuo cujos direitos naturais eram inalienáveis.

Segundo Ibrahim (2008), a sociedade industrial, período de lutas em que trabalhadores buscavam reformas que humanizassem o capitalismo, propiciou o surgimento da proteção social, na medida em que naquele período a classe trabalhadora era dizimada por acidentes de trabalho e pela vulnerabilidade da mão-de-obra infantil.

Daí surgiu a importância da atuação estatal em propiciar a minimização de desigualdades sociais através de mecanismos de segurança social.

Conforme ensinamentos de Rocha e Savaris (2006), os estudos acerca da Seguridade Social exatamente da abordagem acerca do Estado Contemporâneo Democrático, pois foi a partir dele que se deu a consolidação do ideal intervencionista no âmbito social por parte do Estado.

O Estado Contemporâneo Democrático passou a garantir aos cidadãos oportunidades iguais nos âmbitos econômico, social e cultural, por meio da intervenção estatal na sociedade.

Sobre o tema, Rocha e Savaris (2006) discorreram sobre a importância fundamental do Socialismo na formação ideológica do Estado Contemporâneo Democrático, afinal as ideias e ações socialistas pressionaram as sociedades europeias a admitir a flexibilização dos dogmas do Estado Liberal.

Dessa forma, o surgimento da proteção social dos indivíduos quanto aos seus infortúnios se deu tão somente a partir do final do século XIX, afinal, de acordo com Russomano, "o mundo contemporâneo abandonou, há muito, os antigos conceitos da Justiça Cumulativa, pois as novas realidades sociais e econômicas ao longo da História, mostraram que não basta dar a cada um o que é seu para que a sociedade seja justa. Na verdade, algumas vezes, é dando a cada um o que não é o seu que se engrandece a condição humana e que se redime a injustiça dos grandes abismos sociais" (Russomano, Mozart, 1981: 18) (Castro, 2011: 37).

O primeiro ditame legal acerca da concepção de proteção ao trabalhador ocorreu na Declaração dos Direitos do Homem e do Cidadão (1789), na qual foi inscrito o princípio da Seguridade Social como direito subjetivo assegurado a todos.

A partir de então, passou-se a entender que a proteção social do trabalhador era dever da 
sociedade como um todo, sob o aspecto de solidariedade, através da qual todos os trabalhadores contribuiriam para que os necessitados de amparo pudessem usufruir no momento oportuno.

Tal conceito é fundamental para se estabelecer o que vem a ser o seguro social, eis que sem o caráter de proteção de todos por todos, mediante contribuição geral, não há falar em Previdência Social.

No Brasil, a formação de um sistema de proteção social, a exemplo do que se verificou na Europa, ocorreu através do processo de reconhecimento da necessidade de que o Estado intervenha para suprir deficiências da sociedade, postulado fundamental do liberalismo clássico.

Desse modo, partiu-se do assistencialismo para o Seguro Social, e deste para a formação da Seguridade Social. Assim, a referida proteção social encontra-se consolidada na política de Seguridade Social, que por sua vez, abrange o direito à Saúde, à Assistência Social e à Previdência Social, nos termos do atual texto constitucional (art. 194).

Em se tratando de legislação nacional, deve ser considerada como marco inicial da Previdência Social brasileira a publicação do Decreto Legislativo n. 4.682/1923, popularmente conhecido como Lei Eloy Chaves.

Castro e Lazzari (2011) ensinam que através deste Decreto foram criadas as Caixas de Aposentadoria e Pensões nas empresas de estradas de ferro existente, mediante contribuições dos trabalhadores, das empresas do ramo e do Estado, assegurando-se aposentadoria aos trabalhadores e pensão aos respectivos dependentes em caso de morte do segurado, assim como de assistência médica e diminuição do custo de medicamentos.

Com o advento da Constituição da República de 1988, chegou-se ao auge da intervenção do Estado neste setor (amparo social), principalmente por conta da instituição do sistema de Seguridade Social, o qual foi estabelecido como o conjunto integrado de ações de iniciativa dos Podes Públicos e da sociedade destinadas a assegurar os direitos relativos à saúde, à previdência social e à assistência social.

Ibrahim (2008) conceitua o sistema de Seguridade Social como a rede protetiva formada pelo Estado e por particulares no sentido de estabelecer ações sociais positivas no sustento de pessoas carentes, trabalhadores em geral e seus dependentes, providenciando um padrão mínimo de vida.

Por outro lado, Rocha e Savaris (2006) entendem que a Seguridade Social foi concebida como um sistema de prevenção e de reparação das consequências dos riscos sociais para garantir meios de subsistência na ocorrência de terminados fatos, propiciando, dessa forma, a garantia de rendimentos de substituição de renda.

Nessa toada, conclui-se que está garantido legalmente que a Seguridade Social é dever do Estado e direito dos cidadãos, o que faz ampliar a responsabilidade estatal na defesa e garantia dos direitos sociais, a fim de se assegurar a proteção social do trabalhador.

\subsection{PREVIDÊNCIA SOCLAL}

Após apresentados conceito, histórico e sistema de proteção social do trabalhador no Brasil, destacando-se a noção majoritária de que a Previdência Social é um direito subjetivo do indivíduo exercitado em face da sociedade a que pertence, restou claro que os cidadãos hão de participar da regra que envolvem o seguro social por meio de aportes que garantam recursos suficientes à aplicação da política de segurança social.

Como não existe um único meio de se prover aos indivíduos a proteção social com 
relação aos infortúnios que afetem sua capacidade de trabalho e de subsistência, têm-se no âmbito mundial vários modelos de Previdência Social.

O doutrinador Ibrahim (2008) entende que a previdência brasileira comporta dois regimes básicos: Regime Geral de Previdência Social - RGPS e os Regimes Próprio de Previdência dos servidores públicos - RPPS, o qual atende aos servidores ocupantes de cargos efetivos.

Entretanto, imperioso ressaltar que existe, ainda, o Regime de Previdência Complementar, que por sua vez, possui previsão constitucional e encontra-se devidamente regulamentado por legislação infraconstitucional. O regime complementar possui natureza eminentemente privada. Por se tratar de um regime facultativo, é de filiação voluntária e tem por escopo garantir a ampliação ou manutenção de rendimentos do trabalhador na ocasião em que ele passa para a inatividade profissional.

O Regime Geral de Previdência Social, que por sua vez, alcança a maior parte dos trabalhadores do nosso país, é de filiação compulsória possuindo como principal característica a natureza contributiva, nos termos da Constituição Federal (art. 201).

A atuação estatal em matéria de Previdência Social ocorre através da proteção do indivíduo que se enquadre na condição de filiado ao regime e daqueles que se classificam como dependentes dos segurados principais, mediante concessão de benefícios e serviços que caracterizam as prestações previdenciárias.

Portanto, a relação jurídica de natureza previdenciária é aquela em que o individuo filiado ao regime ou seus dependentes figuram como credores, ao passo que o Estado atua como devedor, através da entidade que possui a atribuição de conceder benefícios e serviços. No caso do RGPS, tal entidade se constitui na forma de uma autarquia federal vinculada ao Ministério da Previdência Social - Instituto Nacional do Seguro Social.

Ibrahim (2008) leciona que a natureza jurídica dos regimes básicos previdenciários é institucional, sob o fundamento de que o Estado, através de legislação específica, determina a vinculação automática (compulsória) do trabalhador ao sistema previdenciário, independentemente de sua manifestação de vontade.

Já Rocha e Savaris (2006) destacam que a compulsoriedade do sistema previdenciário brasileiro tem duas justificativas básicas, quais sejam, a conhecida miopia individual, traduzida na pouca importância que os cidadãos jovens depositam no futuro; e a solidariedade previdenciária, a qual garante o pagamento de benefícios até mesmo aos segurados com cotização insuficiente.

Importante ressaltar, também, os ensinamentos de Castro e Lazzari (2011), os quais destacam que o objetivo da relação jurídica previdenciária é a entrega da prestação correspondente ao fato ocorrido com o segurado, seja por meio da obrigação de dar (concessão dos benefícios previdenciários) ou da obrigação de fazer (realização de serviços de reabilitação profissional e decorrentes do serviço social).

Ou seja, o seguro social é direito indisponível para o indivíduo, uma vez que a natureza jurídica, para o ente responsável pela concessão de benefícios e prestação de serviços, é de múnus público, como toda atividade prestada pela Administração Pública na consecução das finalidades das atividades estatais.

É de suma importância destacar que não há qualquer tipo de vinculação previdenciária sem filiação prévia, pois o direito do cidadão à proteção previdenciária somente se perfectibiliza quando este se encontrar filiado ao regime de Previdência Social.

Não obstante, além da necessidade de filiação do segurado para que tenha direito a prestação previdenciária, em alguns casos, dependerá também do cumprimento de um período mínimo de contribuições para que tenha direito a determinados benefícios, lapso conhecido 
como período de carência.

A filiação corresponde ao vínculo jurídico estabelecido entre pessoas que contribuem como segurados para a Previdência Social. Em decorrência de tal vínculo surgem direitos e obrigações.

Os doutrinadores Carlos Alberto Pereira de Castro e João Batista Lazzari ressaltam (Castro e Lazzari, 2011: 169):

"Não se deve confundir a filiação com o pagamento das contribuições. É dizer, existe direito à proteção previdenciária caso o segurado, já filiado (pelo exercício de atividade laboral remunerada que o enquadre como segurado obrigatório), deixe de verter recolhimentos no prazo oportuno. $\mathrm{O}$ mero inadimplemento de contribuições devidas não afasta a filiação, que se mantém durante todo o período em que o segurado de qualquer categoria (exceto facultativo) exercer a atividades (Neste sentido: TRF da $4^{\text {a }}$ Região, AC 2002.72.06.000754-3, da 6 ${ }^{\text {a }}$ Turma, Rel. Des. Federal Victor Luiz dos Santos Laus, DJU 29.09.2004)".

Afinal, a relação de seguro social surge com o exercício de atividade profissional remunerada por parte dos segurados obrigatórios, pois é a partir de então que se dá a sua filiação automática e compulsória ao regime previdenciário a que passa a estar vinculado.

Vale ressaltar o entendimento de Ibrahim (2008), segundo o qual o início da atividade remunerada não necessariamente se coincide com o efetivo começo do trabalho, mas a partir de quando está pactuada a prestação de serviços, ainda que iniciada em outro momento ou com pagamento realizado em outra data.

Assim, percebe-se que para o referido doutrinador, a confirmação de contratação pelo empregador garante ao empregado a filiação ao Regime Geral de Previdência Social.

Por outro lado, em se tratando de segurados facultativos, a relação securitária é iniciada no dia da inscrição ao regime, já que não havendo exercício de atividade laboral remunerada, a relação jurídica é iniciada somente com a manifestação da vontade de filiação ao sistema, fato que se concretiza mediante o pagamento da primeira contribuição.

Nesse diapasão, conforme preceitua o art. $9^{\circ}$, caput, e parágrafos, do Decreto n. 3.048/99, o qual aprovou o Regulamento da Previdência Social e; o art. 11, caput, e parágrafos, da Lei n. 8.213/91, a qual dispõe sobre os Planos de Benefícios da Previdência Social, é segurado da Previdência Social, de forma compulsória, aquela pessoa física que exerce atividade remunerada, efetiva ou eventual, de natureza urbana ou rural, com ou sem vínculo de emprego, a título precário ou não, bem como aquele definido pela lei como tal; ou aquele que exerceu alguma das atividades mencionadas no período imediatamente anterior ao chamado período de graça.

É segurado da Previdência Social também o cidadão que se filia facultativamente, contribuindo para o custeio das prestações sem nem mesmo estar vinculado obrigatoriamente ao Regime previdenciário geral.

Assim, é de se concluir que existem duas espécies de segurados.

Os obrigatórios são aqueles que deverão contribuir compulsoriamente para a Seguridade Social, tendo direito aos benefícios pecuniários previstos na legislação específica e aos serviços oferecidos pela Previdência Social. O pressuposto básico para estar nesse rol é ser pessoa física no exercício de atividade remunerada e lícita, pois a atividade cujo objeto é ilícito não encontra amparo no ordenamento jurídico pátrio.

Em contrapartida, os segurados facultativos desfrutam do privilégio constitucional e legal de filiar-se ao Regime Geral de Previdência Social na hipótese de não estarem enquadrados em nenhum dos tipos de segurado obrigatório e, desde que tenham intenção de contribuir ao 
regime; sejam maiores de 14 anos e não estejam vinculados a nenhum outro regime previdenciário.

O estudioso Ibrahim (2008) sustenta haver uma inversão de procedimento na forma de vinculação ao sistema previdenciário por parte dos segurados facultativos, na medida em que aquela espécie de contribuinte segue a exceção à regra, representada através da sequência inscrição - filiação, ao contrário dos segurados obrigatórios que seguem a ordem filiação inscrição.

Uma vez esclarecidos quem são os segurados da Previdência Social, passa-se a discorrer acerca das prestações da Previdência Social brasileira.

Nos termos do texto constitucional (art. 201), o Regime Geral de Previdência Social deve prestar a cobertura dos eventos de doença, invalidez, morte e idade avançada; proteção à maternidade, especialmente à gestante; proteção ao trabalhador em situação de desemprego involuntário; salário-família e auxílio-reclusão para os dependentes dos segurados de baixa renda e; pensão por morte do segurado falecido ao cônjuge ou companheiro e dependentes.

Ao legislador ordinário coube fixar a cobertura dos eventos acima narrados através de normas de direito público que estabelecem direitos e obrigações entre os indivíduos beneficiários do regime e o Estado. Dessa forma, na ocorrência das hipóteses em que tratam as normas legais, é obrigação do ente previdenciário conceder a prestação prevista na lei, não comportando ao beneficiário a renúncia do direito à prestação que lhe é devida, salvo se pretender que lhe seja concedido algo mais benéfico.

Nesse contexto, para que o cidadão tenha direito à prestação previdenciária é necessário: a) que se encontre enquadrado na qualidade de beneficiário do regime à época do evento; b) a ocorrência de um dos eventos cuja cobertura é devida pelo regime, nos termos da legislação previdenciária vigente na ocasião da ocorrência do fato; c) o cumprimento das exigências legais, como por exemplo, o prazo de carência de contribuições mínimas, idade mínima e ausência de outro benefício não-cumulável com o pretendido e; d) a iniciativa do beneficiário, pois não há pagamento de ofício por parte do ente previdenciário, ou seja, o beneficiário tem de manifestar sua vontade para que o benefício seja concedido através de requerimento ao Instituto Nacional do Seguro Social.

No que diz respeito à cobertura previdenciária aos segurados do RGPS, tem-se os seguintes benefícios: Aposentadoria Por Invalidez; Aposentadoria Por Idade; Aposentadoria Por Tempo de Contribuição; Aposentadoria Especial; Auxílio-doença; Auxílio-acidente, Salário-família e Salário-maternidade. Outrossim, com relação aos dependentes de segurados, os benefícios são: Pensão por morte e Auxílio-reclusão.

\subsection{BENEFÍCIOS POR INCAPACIDADE}

Os benefícios previdenciários que têm como pressuposto a incapacidade laboral objetivam a manutenção da dignidade da pessoa humana para garantir o sustento próprio e da família até a recuperação da capacidade profissional.

Incapacidade laborativa pressupõe impossibilidade para o desempenho das funções profissionais em decorrência de alterações morfopsicofisiológicas provocadas por doença ou por acidente. $\mathrm{Na}$ avaliação da incapacidade profissional é de suma importância se ter em mente que o ponto referencial é a condição clínica do segurado.

Sobre o tema, ensina a Dra. Mara Aparecida Gimenes, médica perita do Instituto Nacional do Seguro Social especializada em Medicina do Trabalho e Auditoria em Saúde (Gimenes, 2014: 17): 
“A incapacidade laboral define-se em uma situação em que o trabalhador, por doença ou acidente, encontra-se impossibilitado para o trabalho e recebe benefício de auxílio-doença ou acidentário da Previdência Social. A capacidade para o trabalho de uma pessoa compreendese na faixa etária de 16 a 65 anos e está condicionada em diferentes aspectos relacionados à saúde. O trabalho poderá ser um fator de risco para a saúde, tais como acidentes de trabalho e doenças ocupacionais. A existência da capacidade laboral depende diretamente das características e exigências do posto de trabalho".

No mesmo sentido, Rocha e Savaris (2006) dissertam que a incapacidade laboral pressupõe a impossibilidade física ou mental para o exercício de uma atividade profissional, decorrente de fatores fisiológicos, tal como a idade avançada, ou patológicos, como enfermidades ou acidentes que comprometem a capacidade de trabalho do segurado.

Na prática, a identificação de incapacidade laborativa ocorre através de perícia médica, na qual se espera que o profissional habilitado (médico) avalie a (in)existência de capacidade clínica para o desempenho das atividades profissionais.

A referida avaliação médica será fundamental para a identificação do grau de incapacidade do segurado da Previdência Social, para fins de se estabelecer qual o benefício previdenciário por incapacidade que dever ser concedido ao trabalhador incapacitado.

Portanto, o conceito de incapacidade deve compreender os seguintes parâmetros: grau, duração e abrangência da tarefa desempenhada.

Quanto ao grau, Gimenes (2014) leciona que a incapacidade laboral pode ser parcial ou total, dependendo da impossibilidade para desempenho das atribuições do cargo: sem apresentar risco de vida ou agravamento (parcial) e, não permitindo atingir a média de rendimento alcançada em condições normais pelos trabalhadores ocupantes do mesmo cargo (total).

Já no que diz respeito à duração, a referida estudiosa entende que a incapacidade pode ser temporária ou permanente, desde que seja considerada a possibilidade de recuperação em prazo previsível (temporária), ou, na hipótese de insuscetibilidade de recuperação.

No tocante à abrangência profissional, a médica ensina que incapacidade se classifica como uniprofissional - aquela em que o impedimento alcança apenas uma atividade específica do cargo, função ou emprego; multiprofissional - impedimento abrange diversas atividades do cargo, função ou emprego ou; omniprofissional - aquela que implica na impossibilidade para o desempenho de toda e qualquer atividade laborativa que vise o sustento próprio ou de sua família.

Dessa forma, é de se concluir que o acometimento de uma doença, por si só, não significa a existência de incapacidade laborativa, pois o que vale na análise oficial do quadro clínico é a repercussão da patologia no desempenho das atribuições profissionais do cidadão.

Nesse diapasão, é de concluir que que a incapacidade profissional temporária pode ser entendida como aquela para a qual se pode esperar recuperação dentro de prazo estimado, ao passo que a incapacidade permanente ocorre quando se trata de insuscetibilidade de recuperação.

Realizadas tais considerações, examina-se a seguir os benefícios previdenciários previstos na lei que regulamenta o Regime Geral de Previdência Social (Lei n. 8.213, de 1991) para o enfrentamento de incapacidade laboral, tidos pelo ordenamento jurídico pátrio como benefícios por incapacidade: Aposentadoria Por Invalidez; o Auxílio-doença e o Auxílio-Acidente. 


\subsubsection{APOSENTADORIA POR INV ALIDEZ}

A Aposentadoria Por Invalidez é o benefício concedido aos trabalhadores que, por doença ou acidente, forem considerados pela perícia médica da Previdência Social incapacitados para o exercício de suas atividades profissionais, ou outro tipo de serviço que lhe garanta o sustento próprio.

Para Castro e Lazzari (2011), nos termos do art. 42 da Lei n. 8.213/91, a aposentadoria por invalidez, uma vez cumprida a carência exigida, quando for o caso, será devida ao segurado que, estando ou não em gozo de auxílio-doença, for considerado incapaz e insuscetível de reabilitação para o exercício de atividade profissional que garante sua subsistência, devendo tal benefício ser pago enquanto o segurado permanecer nesta condição.

De acordo com os ensinamentos de Rocha e Savaris (2006), para a incapacidade genérica e permanente do segurado, o Regime Geral contempla a aposentadoria por invalidez, cujo pressuposto fundamental do deferimento e manutenção do benefício repousa sobre a ausência de capacidade laborativa de forma precária, afinal, paradoxalmente, se o status definitivo da incapacidade vier a se alterar, não subsistirá razão para manutenção daquela prestação previdenciária.

A incapacidade profissional que decorre na insuscetibilidade de recuperação pode, em alguns casos, ser constatada de plano pela perícia médica em face da gravidade das lesões à integridade física ou mental do segurado.

Entretanto, nem sempre a incapacidade permanente e insuscetível de recuperação é identificada imediatamente, razão pela qual, na maioria dos casos concretos, se concede num primeiro momento ao segurado o benefício de auxílio-doença, o qual possui como pressuposto básico a incapacidade profissional temporária e, posteriormente, em caso de conclusão da perícia médica no sentido de que o segurado encontra-se impossibilitado para o exercício de sua atividade profissional de forma permanente, se transforma o benefício inicialmente concedido para aposentadoria por invalidez.

Por esse motivo é que a legislação previdenciária (art. 42 da Lei n. 8.213/91) menciona o fato de que a referida aposentadoria é devida estando ou não o segurado em gozo prévio de auxílio-doença.

Sobre o tema, o jurista Ibrahim (2008) ensina que o fato de o segurado ter recebido anteriormente auxílio-doença é totalmente irrelevante, já que o médico perito possui a prerrogativa de concluir num primeiro momento que o segurado é irrecuperável para sua atividade ou inadaptável para outra.

No mesmo sentido, leciona a professora Cláudia Salles Vilela Vianna (Vianna, 2010: 24):

"O benefício de Aposentadoria por Invalide, previsto na Lei n. 8.213, de 1991, arts. 42 a 47, somente é concedido ao segurado que comprovar documentalmente ao INSS uma incapacidade laborativa insuscetível de recuperação, sendo pago enquanto permanecer essa condição. Não há necessidade de recebimento prévio do benefício de auxílio-doença, sendo possível obtenção da aposentadoria, já de imediato, se o médico perito do INSS constatar que se trata de incapacidade total ou definitiva".

e acordo com os ensinamentos de Gimenes (2014), quanto à perícia médica de identificação da (in)capacidade laboral do segurado, o profissional médico deve levar em consideração não somente a anamnese completa, mas também utilizar-se de um criterioso exame físico.

Outrossim, a referida especialista afirma que "o laudo deve ser fundamentado em elementos técnicos baseados em literatura médica. Anotar nas considerações médico-periciais 
o nome do médico assistente com CRM, descrição dos laudos dos exames complementares, evolução seriada dos exames, agravamento da doença, complicações relacionadas ao tratamento médico para justificar o tempo de concessão de benefício ou o Parecer Contrário à concessão do benefício" (GIMENES, Mara Aparecida: Incapacidade laboral e benefício por auxílio-doença no INSS, São Paulo: Ltr, 2014. p.40-41.).

Importante ressaltar o posicionamento jurisprudencial firmado pelo Superior Tribunal de Justiça quanto aos critérios de avaliação da incapacidade profissional que gera direito ao benefício de Aposentadoria por Invalidez, uma vez que foram definidos importantíssimos parâmetros fundamentais à proteção dos segurados que se encontram em situações de risco, nos seguintes termos:

PREVIDENCIÁRIO. AGRAVO REGIMENTAL NO RECURSO ESPECIAL. APOSENTADORIA POR INVALIDEZ. LAUDO PERICIAL. CONCLUSIVO PELA INCAPACIDADE PARCIAL DO SEGURADO. NÃO VINCULAÇÃO. CIRCUNSTÂNCIA SÓCIO-ECONÔMICA, PROFISSIONAL E CULTURAL FAVORÁVEL À CONCESSÃO DO BENEFÍCIO. RECURSO DESPROVIDO.

1. Os pleitos previdenciários possuem relevante valor social de proteção ao Trabalhador Segurado da Previdência Social, devendo ser, portanto, julgados sob tal orientação exegética.

2. Para a concessão de aposentadoria por invalidez devem ser considerados outros aspectos relevantes, além dos elencados no art. 42 da Lei 8.213/91, tais como, a condição sócio-econômica, profissional e cultural do segurado.

3. Embora tenha o laudo pericial concluído pela incapacidade parcial do segurado, o Magistrado não fica vinculado à prova pericial, podendo decidir contrário a ela quando houver nos autos outros elementos que assim o convençam, como no presente caso.

4. Em face das limitações impostas pela avançada idade, bem como pela baixo grau de escolaridade, seria utopia defender a inserção do segurado no concorrido mercado de trabalho, para iniciar uma nova atividade profissional, motivo pelo qual faz jus à concessão de aposentadoria por invalidez.

5. Agravo Regimental do INSS desprovido.

(AGRESP 200801032030, Quinta Turma, Rel. Min. Napoleão Nunes Maia Filho, DJE 9.11.2009)

Infere-se do julgado cuja ementa foi transcrita acima que os julgadores têm se preocupado com a proteção social do trabalhador, fato devidamente comprovado através do entendimento firmado, no sentido de considerar outros aspectos relevantes para a concessão da Aposentadoria Por Invalidez, dentre eles, as condições sócio-econômicas, profissional e cultural do segurado. Afinal, o julgador não está totalmente adstrito ao laudo pericial produzido no curso da instrução processual.

Destarte, verifica-se a percepção do julgador quanto ao fenômeno denominado incapacidade laboral, a qual não pode ser avaliada tão somente do ponto de vista clínico (médico), mas também em seus aspectos sociais, ambientais e pessoais.

Em suma, para a concessão da Aposentadoria por Invalidez devem ser analisados não somente os requisitos legais previstos na Lei n. 8.213/91, mas também aspectos decorrentes do princípio constitucional da dignidade da pessoa humana.

O período de carência para a concessão deste benefício é de doze contribuições mensais, 
destacando-se que independe de carência os casos de segurados que tenham sofrido acidente de qualquer natureza ou causa; que apresentem quadro clínico compatível com doença profissional ou do trabalho; ou, forem acometidos das seguintes patologias (rol taxativo previsto na Portaria Interministerial n. 2.998/2001): tuberculose ativa; hanseníase; alienação mental; neoplasia maligna; cegueira; paralisia irreversivel e incapacitante; cardiopatia grave; doença de Parkinson; espondiloartrose anquilosante; nefropatia grave; estado avançado de doença de Paget (osteíte deformante); síndrome da deficiência imunológica adquirida-AIDS; contaminação por radiação e hepatopatia grave.

No tocante ao termo inicial do benefício, em se tratando de Aposentadoria por Invalidez decorrente da conversão de auxílio-doença, é devida a partir do dia imediato ao da cessação deste. Contudo, se não decorrer da mencionada transformação de benefício, para os segurados empregados, será devida a partir do décimo sexto dia de afastamento do trabalho, ou, da data de entrada do requerimento administrativo, acaso não pleiteada no prazo de trinta dias após o afastamento do labor. Para os demais segurados, o benefício é devido a partir da data do início da incapacidade definitiva, ou, da data do requerimento administrativo, se formulado após trinta dias do início da incapacidade.

A renda mensal inicial do benefício corresponde a $100 \%$ (cem por cento) do salário de benefício, o qual consiste na média aritmética simples dos $80 \%$ (oitenta por cento) maiores salários de contribuição, contados desde a referência julho/1994 até a data de início do benefício.

Para o segurado aposentado por invalidez que necessitar de assistência permanente de outra pessoa, será acrescido $25 \%$ (vinte e cinco por cento) no valor de seu benefício, conforme disposto no art. 45 da Lei n. 8.213/91. Importante destacar também que tal acréscimo é devido ainda que o valor da aposentadoria atinja o limite máximo legal; assim como é recalculado na medida em que o benefício é reajustado; além de cessar com o falecimento do beneficiário, ou seja, tal benesse não incorpora o valor da pensão por morte devida ao dependente do segurado aposentado por invalidez.

Imperioso destacar o ensinamento de Ibrahim (2008) no que diz respeito ao segurado que se aposenta por invalidez. O referido doutrinador menciona que o segurado naquela situação incapacitante deverá, obrigatoriamente, se afastar de toda e qualquer atividade remunerada, sob pena de cassação do benefício.

Vale anotar que o segurado aposentado por invalidez de idade inferior a sessenta anos está obrigado, a qualquer tempo, a submeter-se a exame médico a cargo da Previdência Social, sob pena de suspensão do benefício.

Isto porque, não obstante a invalidez permanente reconhecida, a Previdência reserva-se ao direito de verificar a continuidade desta condição por meio de perícias médicas escalonadas.

Durante muitos anos o regramento legal sobre a matéria não previu momento em que o benefício de Aposentadoria por Invalidez se tornaria definitivo.

Contudo, com a publicação da Lei n. 13.063, de 2014, o aposentado por invalidez passou a se tornar isento do exame médico para verificação da manutenção da incapacidade laboral permanente a partir do momento em que ele completa sessenta anos de idade.

Dessa forma, o segurado aposentado por invalidez que completa sessenta anos de idade passa a ter o seu benefício garantido como de caráter definitivo.

Por fim, destaca-se que nos termos da legislação trabalhista (CLT, art. 475), a concessão de aposentadoria por invalidez faz suspender o contrato de trabalho, razão pela qual o benefício é automaticamente cancelado na hipótese de retorno voluntário do segurado à 
atividade profissional.

Imperioso destacar, ainda, que a Aposentadoria por Invalidez possui duas espécies: a) previdenciária (comum) para os casos de invalidez não relacionados à atividade profissional do segurado e; b) acidentária, que por sua vez, é devida quando há uma correlação entre as patologias incapacitantes acometidas pelo segurado e a atividade profissional desempenhada.

\subsubsection{AUXÍLIO-DOENCA}

O Auxílio-doença é o benefício previdenciário devido aos segurados que permanecerem incapacitados para o exercício de atividade profissional por período superior a quinze dias. Ou seja, trata-se de benefício devido ao segurado que apresentar incapacidade laboral temporária por mais de quinze dias.

Segundo Castro e Lazzari (2011), o auxílio-doença será devido ao segurado que, após cumprida, quando for o caso, a carência exigida, ficar incapacitado para seu trabalho ou para sua atividade habitual por mais de quinze dias consecutivos. Para os demais segurados, inclusive o doméstico, a Previdência paga o benefício desde o início da incapacidade e quanto a mesma perdurar.

De acordo com Rocha e Savaris (2006), o auxílio-doença se trata do benefício concebido para ser mantido por curtos períodos, ou seja, nas ocasiões em que o segurado se encontra incapacitado para suas ocupações habituais.

Ibrahim (2008), por sua vez, destaca que a principal característica do auxílio-doença é de se tratar de um benefício não-programado, decorrente da incapacidade temporária do segurado para o seu trabalho habitual. Segundo o jurista, a natureza não-programada do auxílio-doença decorre da imprevisibilidade do evento invalidez.

Em suma, a principal diferença entre o auxílio-doença e a aposentadoria por invalidez é a provisoriedade da incapacidade laboral, a qual figura como pré-requisito para a concessão de ambos os benefícios.

Assim como na Aposentadoria Por Invalidez, a concessão do Auxílio-doença depende da caracterização/comprovação da incapacidade laborativa, identificada através de exame realizado pela perícia médica da Previdência Social.

Acerca da necessidade de médicos especialistas para realização das perícias médicas necessárias à concessão do auxílio-doença. A Turma Nacional de Uniformização de jurisprudência sedimentou a matéria da seguinte forma:

- Perícia médica por especialista. A perícia não precisa ser realizada por médico especialista se se trata de doença ou quadro médico simples (PEDILEF ${ }^{\circ}$ 2008.72.51.004841-3/SC, Rel. Juiz Fed. Derivaldo de F. B. Filho, j. em 10-052010).

- Perícia médica por especialista. A perícia deve ser realizada por médico especialista se se trata de doença ou quadro médico complicado, complexo, como, por exemplo, no caso de doença rara. (PEDILEF n ${ }^{\circ}$ 2008.72.51.001862-7/SC, rel. Juíza. Fed. Jacqueline Michels Bilhalva, j. em 10-05-2010).

Portanto, em se tratando de incapacidade laboral decorrente do acometimento de doença rara ou quadro clínico complexo, a perícia médica do INSS deve ser realizada por médico especialista, nos termos dos julgados acima colacionados.

Importante destacar que o auxílio-doença não é devido ao segurado que se filia ao Regime Geral de Previdência Social já sendo portador da doença ou da lesão invocada como causa para concessão do benefício, com exceção dos casos em que a incapacidade sobrevier 
por motivo de progressão ou agravamento daquela patologia incapacitante.

Sobre o tema, registra-se o brilhante entendimento de explanado pelos professores Daniel Machado da Rocha e José Antônio Savaris (Rocha E Savaris, 2006: 274-275):

"É da lógica do seguro social resguardar os trabalhadores contra a ocorrência de eventos nocivos que possam surgir após a materialização da filiação. No regime geral, para que alguém recolha a primeira contribuição não é imposta a realização de um exame admissional. Por isso, é incomum que um segurado busque a tutela do regime previdenciário após a materialização dos efeitos nocivos da incapacidade laboral. Se a doença ou a lesão invocada como causa para o deferimento de auxílio-doença ou aposentadoria por invalidez é anterior à filiação, fica afetada a ideia de seguro. Nestes casos, o sistema tende a negar o seu amparo (LBPS, §2 do art. 42 e parágrafo único do art. 59), pois, caso contrário, estar-se-ia estimulando os segurados, em especial os que trabalham por conta própria (contribuintes individuais) e não serem previdentes. Excepcionalmente, quando a incapacidade resultar do agravamento ou progressão da lesão já existente, mas cuja gravidade não impedia o segurado de exercer atividades laborais, o amparo previdenciário é concedido. Em princípio, a preexistência ou não, da incapacidade é questão a ser esclarecida, com base na técnica, pelos peritos. Entretanto, a jurisprudência tem temperado esta norma, valorando a boa-fé do segurado no momento da filiação."

Portanto, verifica-se que não é devido o auxílio-doença requerido pelo segurado com fulcro na incapacidade laborativa provisória decorrente de doença preexistente à filiação do segurado ao RGPS.

O segurado que possui dois vínculos empregatícios e se tornar incapaz para o trabalho, ainda que somente para uma das atividades profissionais, terá direito à concessão do auxíliodoença.

Nesse sentido, ensinam os professores Carlos Alberto Pereira de Castro e João Batista Lazzari (Castro e Lazzari, 2011: 671):

"O auxílio-doença do segurado que exercer mais de uma atividade abrangida pela Previdência Social será devido, mesmo no caso de incapacidade apenas para o exercício de uma delas, devendo a perícia médica ser conhecedora de todas as atividades que o mesmo estiver exercendo. Neste caso, o benefício será concedido em relação á atividade (ou atividades, caso exercida mais de uma, concomitantemente) para a qual o segurado estiver incapacitado, considerando-se para efeito de carência somente as contribuições relativas a esta atividade. Se nas várias atividades o segurado exercer a mesma profissão, será exigido de imediato o afastamento de todas (Art. 73 do Decreto n. 3.048/99)".

Sobre o tema, Ibrahim (2008) destaca que o auxílio-doença do segurado que possui mais de uma atividade remunerada e encontra-se incapaz para somente uma delas, será calculado levando-se em consideração apenas os salários de contribuição da atividade para a qual o segurado se encontra incapacitado, sendo o benefício recalculado no caso de a incapacidade se estender para as demais atividades desenvolvidas pelo segurado.

Quanto à carência para a concessão do auxílio-doença, as regras são as mesmas aplicáveis ao benefício de Aposentadoria Por Invalidez, quais sejam, de doze contribuições mensais, exceto quando a incapacidade decorrer de acidente de qualquer natureza ou causa; ou, quando o segurado estiver acometido pelas patologias constantes no rol taxativo previsto na Portaria Interministerial n. 2.998/2001, situações em que a concessão do benefício independerá de carência.

Para o segurado empregado o benefício será devido a partir do décimo sexto dia do afastamento da atividade profissional, ao passo que para os demais segurados, é devido a 
partir da data da incapacidade. Dessa forma, resta claro que durante os primeiros quinze dias consecutivos ao do afastamento da atividade laboral por motivo de doença, caberá ao empregador arcar com o salário integral do trabalhador.

Nos termos do que preceitua o art. 60, $\S 1^{\circ}$, da Lei n. 8.213/91, o auxílio-doença será devido a partir da data do requerimento de concessão nos casos em que for pleiteado após trinta dias do afastamento da atividade profissional ou do início da incapacidade laborativa.

Nessa seara, Castro E Lazzari (2011) discorrem que quando o requerimento do segurado afastado da atividade (inclusive o empregado) for protocolizado depois do trigésimo dia de afastamento, o benefício será devido apenas a contar da data de entrada do requerimento, não retroagindo ao décimo sexto dia, no caso do segurado empregado, nem ao primeiro dia de afastamento, para os demais segurados. Penaliza-se, desta forma, a inércia do segurado em buscar o benefício.

Nos casos de concessão de novo benefício em decorrência da mesma doença, dentro do período de sessenta dias contados da cessação do benefício anterior, a empresa empregadora fica desobrigada do pagamento relativo aos quinze primeiros dias de afastamento, pois deve ser prorrogado o benefício anterior, descontando-se os dias trabalhados, se for o caso.

Outrossim, se o segurado empregado afastar-se do trabalho por motivo de doença durante quinze dias, retornando à atividade no décimo sexto dia, e se dela voltar a se afastar no prazo de sessenta dias contados do retorno, fará jus ao auxílio-doença a partir da data do novo afastamento, ainda que a doença seja a mesma.

Ademais, acaso o segurado empregado tenha se afastado do trabalho por menos de quinze dias, e tornar a se afastar dentro de sessenta dias, caberá à empregadora pagar apenas os dias faltantes para completar os quinze dias de afastamento, devendo o segurado ser encaminhado à Previdência Social para a concessão do benefício no décimo sexto dia de afastamento, computados ambos os períodos.

A renda mensal inicial do benefício corresponde a $91 \%$ (noventa e um por cento) do salário de benefício, o qual consiste na média aritmética simples dos $80 \%$ (oitenta por cento) maiores salários de contribuição, contados desde a referência julho/1994 até a data de início do benefício.

No mesmo sentido da Aposentadoria por Invalidez, a concessão do auxílio-doença faz suspender o contrato de trabalho entre empregado e empregador.

O auxílio-doença será mantido enquanto o segurado permanecer incapacitado para o exercício das atividades profissionais independentemente do tempo em que se encontra em gozo do benefício, podendo o INSS encaminha-lo para procedimento de reabilitação profissional. Dessa forma, imperioso dizer que o benefício não pode cessar até que o segurado tenha recuperado a capacidade laboral; seja considerado habilitado para o desempenho de outra atividade profissional que lhe garanta subsistência e; se considerado incapacitado definitivamente, seja aposentado por invalidez.

Ou seja, o auxílio-doença cessa pela recuperação da capacidade para o trabalho ou pela transformação em aposentadoria por invalidez ou auxílio-acidente, neste caso se resultar sequela que implique redução da capacidade para o trabalho que habitualmente exercia.

Por fim, destaca-se que o auxílio-doença também possui duas espécies: a) auxílio-doença previdenciário (ou comum), o qual é identificado pela Previdência Social sob o Código B-31. É concedido ao segurado impedido de trabalhar por motivo de doença ou acidente que não guardem qualquer correlação com a atividade profissional desempenhada e; b) auxílio-doença acidentário, identificado sob o código B-91. Concedido ao segurado que sofre acidente de trabalho, inclusive o de trajeto, ou, àquele que se torna acometido por doença profissional 
(lesões advindas das atividades profissionais).

Sobre o auxílio-doença acidentário, Ibrahim (2008) destaca que tal benefício sempre dispensará de carência, e somente nesta espécie é que se gera a estabilidade empregatícia provisória de doze meses ao empregado.

Já a doutrinadora Vianna (2010), menciona que se a incapacidade for verificada pela perícia do INSS como decorrente de acidente de qualquer natureza, o benefício será identificado como auxílio-doença acidentário.

\subsubsection{AUXÍLIO-ACIDENTE}

O Auxílio-acidente consiste no benefício previdenciário pago ao segurado empregado (exceto doméstico), trabalhador avulso e ao segurado especial, como forma de indenização, após a consolidação de lesões decorrentes de acidente de qualquer natureza em que resultar sequelas que impliquem na redução da capacidade laborativa.

Cuida-se do único benefício previdenciário que possui natureza jurídica exclusivamente indenizatória, pois visa o ressarcimento ao segurado do acidente que lhe provocou a redução da capacidade para o desempenho das atividades profissionais.

Castro E Lazzari (2011) conceituam o auxílio-acidente como o benefício previdenciário pago mensalmente ao segurado acidentado como forma de indenização, sem caráter substitutivo de salário, pois é recebido cumulativamente com o mesmo, quando, após a consolidação das lesões decorrentes de acidente de qualquer natureza - a não somente de acidentes de trabalho -, resultarem sequelas que impliquem redução da capacidade para o trabalho que habitualmente exercia.

O jurista Ibrahim (2008) destaca que a concessão do auxílio-acidente depende obrigatoriamente da tríade: acidente de qualquer natureza (inclusive do trabalho), produção de sequela definitiva e efetiva redução da capacidade laborativa diretamente relaciona à sequela.

O objetivo do auxílio-acidente é complementar os gastos de quem se encontra com a capacidade para o trabalho reduzida ou sem condições de auferir renda compatível com sua antiga habilitação profissional, razão pela qual possui natureza eminentemente indenizatória. Ou seja, tem por finalidade social compensar o segurado pelo fato de não possuir plena capacidade do trabalho que habitualmente exercia em razão do acidente de qualquer natureza.

Convém ressaltar que não há motivo para confundir o auxílio-acidente com o auxíliodoença, pois este somente é devido na ocasião de o segurado se encontrar incapaz temporariamente para o trabalho, ao passo que aquele é devido após a consolidação de lesões e/ou perturbações funcionais de natureza acidentária, não sendo percebido cumulativamente com o auxílio-doença, mas tão somente após a cessação deste último.

Outrossim, mister destacar que se trata de um benefício concedido em caráter provisório, justamente pelo fato de o segurado estar, a qualquer momento, suscetível de recuperação da capacidade laboral cuja redução decorreu na concessão do benefício.

É devido a partir do momento em que a perícia médica da Previdência Social concluir pela existência de sequela definitiva enquadrada como redução da capacidade funcional, considerando-se para tal fim a atividade realizada pelo segurado na época do acidente.

Portanto, o legislador deixou claro que o dano, decorrente de acidente de qualquer natureza, capaz de ensejar a concessão do auxílio-acidente é aquele que acarreta perda ou redução da capacidade de trabalho, sem caracterização de invalidez permanente para toda e qualquer atividade profissional.

Sobre o tema, o Superior Tribunal de Justiça estabeleceu que o segurado que tenha 
adquirido lesão causadora de incapacidade parcial e permanente possui direito a receber o auxílio-acidente, ainda que tal lesão tenha caráter reversível, senão vejamos:

“(...) estando devidamente comprovado o nexo de causalidade entre a redução parcial da capacidade para o trabalho da pessoa e o exercício de suas funções laborais habituais, não é cabível afastar a concessão do auxílio-acidente somente pela possibilidade de desaparecimento dos sintomas da patologia que acomete o segurado, me virtude de tratamento ambulatorial ou cirúrgico.”. (AgRg no REsp 798913/SP, Quinta Turma, Rel. Min. Arnaldo Esteves Lima, Dje 01-02-2010).

Nesse sentido, Ibrahim (2008) ressalta que a manutenção da concessão do benefício independe da mudança de atividade profissional ou do possível desemprego do segurado, pois a concessão do benefício leva em consideração a atividade exercida pelo segurado na época do acidente.

Com relação à carência, vale mencionar que a concessão de tal benefício independe do número de contribuições mínimas, embora seja preciso ter a qualidade de segurado para fazer jus ao benefício.

O pagamento do benefício tem início a partir do dia seguinte ao do término do auxíliodoença, ou, da data de entrada do requerimento administrativo, quando não precedido de auxílio-doença. Por outro lado, a extinção do auxílio-acidente se dá com a concessão de Aposentadoria ou com o falecimento do segurado beneficiário.

Destaca-se que o auxílio-acidente, por se tratar de benefício de caráter indenizatório, pode ser cumulado com o salário do trabalhador, sendo vedada sua cumulação com qualquer das modalidades de aposentadoria concedidas pelo Regime Geral de Previdência Social, ou com novo auxílio-doença que possa vir a ser concedido ao segurado.

A renda mensal inicial do benefício corresponde atualmente a $50 \%$ (cinqüenta por cento) do salário de benefício, nos termos da Lei n. 9.032/95. Antigamente, de acordo com o texto original da Lei n. 8.213/91, a renda mensal inicial do benefício estava diretamente relacionada à gravidade das seqüelas apresentadas pelo segurado, podendo corresponder a 30\%, 40 ou $60 \%$ sobre o salário de contribuição do segurado vigente na época do acidente.

Sobre o tema, ensinam os doutrinadores Daniel Machado da Rocha e José Antônio Savaris (Rocha e Savaris, 2006: 302).

"Pelos critérios atuais, a renda mensal será, em qualquer caso, de 50\% do salário-debenefício. Em linhas de princípio, o benefício deverá ser calculado de acordo com lei vigente na data da consolidação das sequelas, inexistindo direito à revisão de benefícios concedidos com coeficiente menor em virtude de acidentes anteriores à lei atual".

Nesse interim, o Superior Tribunal de Justiça pacificou entendimento no sentido de que é cabível estender a incidência da lei nova, a qual é mais vantajosa ao segurado, não somente aos benefícios pendentes, mas a todos os segurados, independentemente da lei vigente na data do sinistro:

AÇÃO RESCISÓRIA. PREVIDENCIÁRIO. INAPLICABILDADE DA SÚMULA 34/STF. CONTROVÉRSIA INSTAURADA QUANTO AS DISPOSIÇÕES DAS LEIS 8.213/91 E 9.032/95. AUXÍlLIO-ACIDENTE E MAJORAÇÃO DO SEU PERCENTUAL PARA 50\%. POSIBLIDADE A PARTIR DA VIGÊNCIA DA LEI 9.032/95. PRECEDENTES. PEDIDO IMPROCEDNTE.

1. O texto enunciado de $\mathrm{n}^{\mathrm{o}} 343$ da súmula do STF não se aplica quando a controvérsia for em relação a texto constitucional. Versando a hipótese sobre o benefício de auxílio-acidente e sua majoração, o deslinde da questão se dará à luz 
das disposições das Leis $\mathrm{n}^{\mathrm{o}}$ 8.213/91 e 9.032/95, inexistindo óbice ao prosseguimento da rescisória.

2. O aumento do percentual relativo a $50 \%$ do auxílio-acidente deve ser aplicado imediatamente, atingindo todos segurados que estiverem na mesma situação, sem exceção, seja referente aos casos pendentes de concessão ou os já concedidos. A questão encerra uma relação jurídica continuativa, sujeita a pedido de revisão quando modificado o estado de fato, passível, pois, de atingir efeitos futuros de atos constituídos no passado, sem implicar retroatividade da lei.

3. A Terceira Seção já firmou entendimento segundo o qual, tratando-se de benefício acidentário, a legislação moderna, mais benéfica ao segurado, tem aplicação imediata. Todavia, o percentual de 50\%, previsto na Lei 9.032/95, só passa a ter efeitos a partir da sua vigência.

4. Ação improcedente.

(STJ, Terceira Seção, AR 4217/SP. Rel. Min. Maria Thereza de Assis Moura, j. em 14-10-2009)

Desse modo, a Lei n. 9.032/95 é aplicável para majorar a renda mensal inicial dos benefícios concedidos anteriormente a sua entrada em vigor, conforme o julgado cuja ementa foi transcrita acima.

\subsection{ACIDENTE DE TRABALHO}

A legislação define o acidente de trabalho como aquele que ocorre pelo exercício do trabalho a serviço da empresa ou não, provocando lesão corporal ou perturbação funcional, permanente ou temporária, que causa a morte, a perda ou a redução da capacidade laboral. Ou seja, de acordo com o conceito legal, o acidente de trabalho é aquele que decorre do exercício do trabalho a serviço da empresa ou decorrente do trabalho prestado pelos segurados especiais.

Ocorre que, sob o ponto de vista doutrinário, o conceito trazido pela legislação não é suficiente para se ter a noção adequada do que de fato seja o acidente de trabalho, pois tal definição se presta tão somente a indicar os segurados que têm direito à proteção acidentária.

Dessa forma, para se ter um conceito mais apropriado acerca daquilo que efetivamente corresponde ao acidente de trabalho, é preciso socorrer a estudiosos do tema, dentre eles, Russomano, que o definiu com amparo na doutrina francesa:

"O acidente de trabalho, pois, é um acontecimento em geral súbitom violento e fortuito, vinculado ao serviço prestado a outrem pela vítima que lhe determina lesão corporal. (Por aproximação, podemos dizer que é esse o pensamento de Rouast e Givord "Traité sur Accidents du Travail”, p. 92)" (Russomano, 1981: 395) (Castro, 2011: 570)

Nesse diapasão, o acidente de trabalho pode ser conceituado como toda lesão corporal ou perturbação da capacidade funcional que, no exercício do trabalho ou por motivo dele, resultar de causa externa, súbita, imprevista ou fortuita, que causa a morte ou a incapacidade para o trabalho, total ou parcial, permanente ou temporária.

Pacheco (2014) afirma que, historicamente, o acidente de trabalho tinha conceito restrito, pois era considerado por trabalhadores e por empregadores como uma fatalidade, ou seja, fruto do acaso ou falta de sorte. Era encarado como algo que não pudesse ser evitado.

Entretanto, ao longo dos anos o conceito de acidente de trabalho evoluiu, deixando de ser considerado como mera fatalidade, mediante adequação à realidade do direito 
constitucional, que reconhece a dignidade da pessoal humana e o valor social do trabalho.

Desse modo, dizer que o acidente de trabalho decorre de evento causado por agente externo significa que o infortúnio que atinge o trabalhador não lhe é congênito, nem se trata de patologia preexistente.

Nesse mesmo sentido, Sobrinho (2012) leciona que o conceito de acidente de trabalho contido na legislação contempla uma percepção mais restrita do fenômeno acidentário. $\mathrm{O}$ autor entende que, numa visão de senso comum, o acidente é visto como um momento de azar, uma casualidade que resulta num dano para o trabalhador.

Oliveira (2006), por sua vez, ressalta que o conceito de acidente de trabalho passou aperfeiçoamentos ao longo dos anos, destacando que anteriormente o foco da definição estava centrado na lesão produzida, mas num segundo momento foi alterado para os fatores causais.

Outrossim, vale mencionar que a violência caracterizadora do acidente de trabalho é aquela no sentido de que produz violação à integridade do obreiro, da qual resulta a lesão corporal ou a perturbação funcional que o torna incapaz ou causa a morte.

A subtaneidade, por sua vez, se reporta ao fato causador, que ocorre em curto lapso temporal, mas possui efeitos que podem perdurar por muito tempo.

E, por último, a existência do acidente de trabalho pressupõe tenha ele decorrido do exercício da atividade laboral, ou seja, no âmbito dos deveres e obrigações impostos pela relação de trabalho, ainda que o fato tenha ocorrido fora do ambiente profissional.

Os professores Castro e Lazzari (2011, p. 571) destacam situações hipotéticas que também devem ser reconhecidas como acidente de trabalho:

"Retomando o conceito atribuído pelo legislador, também se considera acidente de trabalho o ocorrido no local e no horário de trabalho por agressão, sabotagem ou terrorismo praticado por terceiro ou companheiro de trabalho; ofensa física intencional, inclusive de terceiro, por motivo de disputa relacionada com o trabalho; ato de imprudência, negligência ou imperícia de terceiro ou companheiro de trabalho; ato de pessoa privada do uso da razão; casos fortuitos ou de força maior; em quaisquer local e horário, em caso de contaminação acidental do segurado no exercício de sua atividade; na execução de ordem ou realização de serviço sob a autoridade da empresa; na prestação espontânea de qualquer serviço à empresa, inclusive para fins de estudo quando financiada por esta; no percurso residência-local de trabalho e vice-versa; nos períodos destinados à refeição ou descanso intrajornada, ou satisfação de outras necessidades fisiológicas, no local do trabalho ou durante este, sendo nessas oportunidades considerado no exercício do trabalho - art. 21 da Lei n. 8.213/91" (Castro e Lazzari, 2011: 571)

As situações acima relacionadas são aquelas consideradas acidente de trabalho por equiparação, conforme a previsão legal. Em apertada síntese, possuem os mesmos efeitos do acidente de trabalho quando ocorridos.

Conforme mencionado anteriormente, o elemento objetivo fundamental para fins de caracterização do acidente de trabalho é a existência da lesão corporal ou da perturbação funcional que ocasionem a morte ou a perda, ainda que temporária, da capacidade laboral.

Imperioso ressaltar que a lesão corporal pode ser considerada aquela que atinge a integridade física do indivíduo, capaz de causar dano físico-anatômico, ao passo que a perturbação funcional é aquela que apresenta dano fisiológico ou psíquico diretamente relacionado aos órgãos ou funções específicas do organismo humano.

É cediço que o acidente do trabalho se trata de um gênero do qual são espécies o acidente laboral em sentido estrito e as doenças ocupacionais. O primeiro é chamado de acidente típico ou acidente tipo, sendo normalmente um fato imprevisível, súbito, que ocorre 
com o trabalhador no ambiente de trabalho. As doenças ocupacionais, que compreendem as doenças profissionais e do trabalho, são eventos que vão minando a saúde do trabalhador com o passar do tempo, cujos sintomas por vezes são percebidos muito tempo depois de sua aquisição pelo organismo humano (Silva, 2014).

Assim, fica claro que ao lado da conceituação explanada anteriormente, a qual corresponde ao acidente de trabalho típico, nos termos da legislação previdenciária, as doenças profissionais e/ou ocupacionais enquanto entidades mórbidas também são consideradas acidente do trabalho.

Segundo a legislação (art. 20 da Lei n. 8.213/91), a doença profissional corresponde àquela produzida ou desencadeada pelo exercício do trabalhar peculiar a determinada atividade, assim como a doença do trabalho é aquela adquirida ou desencadeada em função de condições especiais em que o trabalho é realizado e com ele se relaciona diretamente.

Como visto, e corroborado por alguns doutrinadores, existem três espécies de acidente de trabalho: acidente típico (tipo); doenças ocupacionais e acidente por equiparação.

\subsubsection{ACIDENTE TÍPICO (TIPO)}

O acidente de trabalho típico, também chamado de tipo, macrotrauma ou acidente propriamente dito, corresponde ao acontecimento brusco, repentino, inesperado, externo e traumático, ocorrido durante o trabalho ou em razão dele e que atinge a integridade física ou psíquica do trabalhador.

Trata-se do acidente de trabalho cujo conceito está previsto no art. 19, da Lei n. 8.213/91:

"Art. 19 - Acidente do trabalho é o que ocorre pelo exercício do trabalho a serviço da empresa ou pelo exercício do trabalho dos segurados referidos no inciso VII do art. 11 desta Lei, provocando lesão corporal ou perturbação funcional que causa a morte ou a perda ou redução, permanente ou temporária, da capacidade para o trabalho."

Percebe-se que o supracitado dispositivo legal é expresso no tocante à necessidade de que o acidente decorra do exercício do trabalho a serviço da empresa. Dessa forma, a lei visa a garantia de uma relação de causalidade entre a atividade do obreiro e o sinistro.

O jurista José Antônio Ribeiro de Oliveira Silva (2014) conceitua o acidente típico como "um evento único, imprevisto, que ocorre de súbito, de consequências geralmente imediatas, podendo ser leves, graves e até fatais.".

No mesmo sentido, Pacheco (2014) ensina que o acidente tipo ou típico figura como a primeira modalidade de acidente do trabalho, caracterizado pela subtaneidade, evento repentino, ocasionado, em regra, por agente externo, em virtude de falta de atenção do segurado ou por negligência da empresa na observância das condições de segurança e higiene no local de trabalho.

E, da mesma forma, Sobrinho (2012) ensina que tal espécie de acidente de trabalho, além de caracterizada pela causa única, súbita e externa, decorre do exercício das atividades do trabalho que em regra é prestado em proveito de outrem. Dessa forma, segundo aquele jurista, o acidente típico além de reportar-se a um dado espaço e um registro temporal do evento danoso, é caracterizado pela instantaneidade e pelo acontecimento brusco, repentino, traumático, inesperado e que emergiu durante a execução do contrato de trabalho.

Nesse diapasão, além das características genéricas de acidente de trabalho acima mencionadas, no que diz respeito à configuração do acidente típico, se exige os requisitos 
lesividade e nexo de causalidade.

A lesividade consiste no fato de que só se considera acidente do trabalho o fato que provoque lesão corporal ou perturbação funcional de qualquer das funções do organismo humano e, desde que provoque a morte, perda ou redução da capacidade para o desempenho das atividades laborativas. Já o nexo causal, constitui a relação de causa e efeito entre o evento e o resultado.

No que diz respeito à relação de causa e efeito, o professor Odonel Urbano Gonçalves salienta que há, no conceito de acidente do trabalho, uma tríplice relação assim exprimida: a) trabalho-acidente. b) acidente-lesão; e c) lesão-incapacidade de causalidade. Entre o acidente e o trabalho, se não houver relação, exceto nas hipóteses previstas na lei, não haverá infortúnio do trabalho ocorrendo acidente mas sem lesão, não haverá reparabilidade. E, mesmo havendo lesão, se esta não for incapacitante para o trabalho, não haverá reparação. (Gonçalves, 2004: 154) (Pacheco, 2014: 47).

\subsubsection{DOENCAS OCUPACIONAIS}

Castro e Lazzari (2011) conceituam as doenças ocupacionais como aquelas deflagradas em virtude da atividade laborativa desempenhada pelo indivíduo.

Já Sobrinho (2012) entende que as doenças ocupacionais são moléstias que provocam alterações na saúde do trabalhador e reportam-se ao gênero que compreende duas espécies: as doenças profissionais e as doenças do trabalho.

Para Oliveira (2006), diante do significado específico de doença profissional e de doença do trabalho, a denominação doenças ocupacionais passou a ser adotada como o gênero mais próximo que abrange as modalidades das doenças relacionadas com o trabalho.

Ao contrário do acidente típico, que ocorre de forma inopinada, as doenças ocupacionais se instalam de forma traiçoeira, pouco a pouco, contaminando a resistência do trabalhador de forma muito lenta.

Corroborando o entendimento doutrinário acima destacado, registra-se que em se tratando de doença ocupacional, a Lei n. 8.213/91 regula o tema doenças ocupacionais como gênero que contém duas espécies: doença profissional e doença do trabalho, na forma dos incisos $I$ e $I I$, do art. 20, in verbis:

"Art. 20 - Consideram-se acidente do trabalho, nos termos do artigo anterior, as seguintes entidades mórbidas:

I - doença profissional, assim entendida a produzida ou desencadeada pelo exercício de trabalho peculiar a determinada atividade e constante da respectiva relação elaborada pelo Ministério do Trabalho e da Previdência Social;

II - doença do trabalho, assim entendida a adquirida ou desencadeada em função de condições especiais em que o trabalho é realizado e com ele se relacione diretamente, constante da relação mencionada no inciso I."

Sobre elas, elucidou Pacheco: "As doenças profissionais são de dois tipos: há umas que só são produzidas por determinadas espécies de trabalho, tendo uma outra característica que é a insalubridade. São doenças profissionais típicas ou tecnopatias, isto é, doenças próprias da técnica, do trabalho especializado. Por outro lado, temos as doenças profissionais atípicas, que são as não peculiares a um determinado tipo de trabalho. São doenças comuns que qualquer pessoa pode ter; mas que o trabalhador adquire em virtude das condições do seu trabalho, condições especiais ou excepcionais, como, por exemplo, as do trabalho num calor muito elevado ou no frio, ou sujeito a insolações. São doenças atípicas ou mesopatias, doenças do 
meio, do ambiente, doenças ambientais. A característica, portanto, é o condicionamento. Dependem das condições em que o trabalho é realizado.". (Iara Alves Cordeiro: Acidente do Trabalho: Causas e consequências da sonegação da CAT, São Paulo: Ltr, 2014, p. 48).

Oliveira (2006) entende que a doença profissional é aquela cujo nexo causal da doença é presumido em decorrência do exercício de determina profissão, não cabendo prova em sentido contrário, uma vez que bastaria a comprovação da prestação do serviço na atividade e o cometimento da doença profissional.

Em suma, classificam-se como doença profissional aquelas decorrentes de situações comuns aos integrantes de uma determinada categoria profissional de trabalhadores, conforme relacionado no Anexo II, do Decreto n. 3.048/99 ou; na hipótese de comprovação do nexo causal entre a doença e a lesão, independentemente de constar na referida relação.

Exemplificando, são doenças comuns aos profissionais de certa atividade profissional, tal como a pneumoconiose, entre os mineiros. Nesse sentido, ensina a professora Iara Alves Cordeiro (2014, p. 49):

"Podemos citar como exemplos de doenças profissionais a bissinose, a pneumocarnose, a siderose, a absestose, a LER/DORT e a perda auditiva (PAIR).

A bissinose ataca os profissionais que trabalham com algodão.

Ocorre a pneumocarnose ou bagaçose com os que atuam no ramo da cana de açúcar, cujas fibras da cana esmagada são assimiladas pelo sistema respiratório.

Os que trabalham com ferro, inalando as partículas, podem sofrer siderose.

A asbestose atinge os trabalhadores que atuam com amianto, que provoca câncer no pulmão.

As lesões de esforço repetitivo (tenossinovite, tendinite, síndrome do túnel de carpo) são doenças que atingem os músculos, tendões e nervos superiores. Constituem inflamações decorrentes de atividades que demandam movimentos repetitivos, como é o caso dos digitadores, telefonistas, operários da linha de montagem e outros.

A perda auditiva ocorre com trabalhadores que atuam em locais com altos níveis de ruído, durante largo espaço de tempo." (Cordeiro, 2014: 49).

Silva (2014) ensina que as doenças profissionais são conhecidas, ainda, com o nome de "idiopatias", "ergopatias", "tecnopatias" ou "doenças profissionais típicas". Cuidam-se de doenças produzidas ou desencadeadas pelo exercício profissional peculiar a determinada atividade, ou seja, são doenças que decorrem necessariamente do exercício de uma profissão, razão pela qual, segundo aquele doutrinador, prescindem de comprovação do nexo de causalidade com o trabalho, porquanto há uma relação de tipicidade, presumindo-se por lei, que decorrem de determinada atividade profissional.

Portanto, a doença profissional é causada pela própria atividade prestada pelo trabalhador, eis que no exercício de tal atividade se dá a atuação do fator patogênico que adoece o obreiro.

No tocante à caracterização das doenças profissionais, Russomano observa que elas precisam conter algumas características patogênicas, dentre elas: a) os sintomas devem ser idênticos, aparecendo em vários trabalhadores que se dedicam à mesma profissão, no mesmo estabelecimento, ou, preferencialmente, em estabelecimentos distintos, ocasião em que estará mais bem definido o caráter profissional da doença e; b) deve restar claramente evidenciado que a doença tem como causa a atividade desenvolvida pelo trabalhador na empresa, seja pelas condições do serviço (no subsolo, por exemplo), seja pelos métodos empregados (levantamento de pessoas pela força muscular), seja, ainda, pelos materiais utilizados (tóxicos). (Russomano, 2014: 152). 
Quanto às doenças do trabalho, diferentemente da doença profissional, não estão necessariamente ligadas à profissão, pois o cometimento de tais patologias decorre da forma em que o trabalhador é prestado ou das condições específicas do ambiente de trabalho. Isto porque, as condições excepcionais ou especiais do trabalho determinam a o rompimento da resistência orgânica do ser humano, desencadeando na eclosão ou exacerbação do quadro mórbido.

Silva (2014) conceitua as doenças do trabalho, as quais também são denominadas "mesopatias" ou "doenças profissionais atípicas", como aquelas desencadeadas em função de condições especiais em que o trabalho é realizado e com ele se relacionam diretamente.

Oliveira (2006) entende que tal espécie não está diretamente vinculada à determinada profissão, pois seu aparecimento decorre da forma com que o trabalho é prestado, bem como das condições específicas do ambiente laboral.

Castro e Lazzari (2011) conceituam a doença do trabalho como aquela adquirida e desencadeada em função de condições especiais em que o trabalho é realizado e com ele se relacione diretamente. É o caso, por exemplo, de um empregado de casa noturna cujo "som ambiente" supere os limites de tolerância. Neste caso, a atividade profissional não geraria nenhuma doença ou perturbação funcional auditiva, contudo, pelas condições em que exerce o trabalho, ele está sujeito ao agente nocivo - ruído excessivo.

Outro exemplo muito utilizado pela maioria dos doutrinadores é o caso dos "Distúrbios do Sistema Osteomuscular Relacionados ao Trabalho - DORT”, dos quais decorrem as Lesões por Esforços Repetitivos - LER. São casos em que, sob o prisma ergonômico, as condições inadequadas no ambiente de trabalho desenvolvem patologias típicas.

Portanto, a doença do trabalho não está vinculada a determinada profissão, mas pode ocorrer no exercício de qualquer delas, em virtude das condições em que o trabalho é segurado.

\subsubsection{ACIDENTE DE TRABALHO POR EQUIPARAÇÃO}

Além dos casos específicos anteriormente apresentados, existem, ainda, os acidentes de trabalho por equiparação, os quais possuem relação apenas indireta com a atividade desenvolvida pelo trabalhador.

$\mathrm{O}$ art. 21 da Lei n. 8.213/91 dispõe as situações equiparadas a acidente de trabalho, in verbis:

Art. 21. Equiparam-se também ao acidente do trabalho, para efeitos desta Lei:

I - o acidente ligado ao trabalho que, embora não tenha sido a causa única, haja contribuído diretamente para a morte do segurado, para redução ou perda da sua capacidade para o trabalho, ou produzido lesão que exija atenção médica para a sua recuperação;

II - o acidente sofrido pelo segurado no local e no horário do trabalho, em conseqüência de:

a) ato de agressão, sabotagem ou terrorismo praticado por terceiro ou companheiro de trabalho;

b) ofensa física intencional, inclusive de terceiro, por motivo de disputa relacionada ao trabalho;

c) ato de imprudência, de negligência ou de imperícia de terceiro ou de companheiro de trabalho; 
d) ato de pessoa privada do uso da razão;

e) desabamento, inundação, incêndio e outros casos fortuitos ou decorrentes de força maior;

III - a doença proveniente de contaminação acidental do empregado no exercício de sua atividade; de trabalho:

$I V$ - o acidente sofrido pelo segurado ainda que fora do local e horário

a) na execução de ordem ou na realização de serviço sob a autoridade da empresa;

b) na prestação espontânea de qualquer serviço à empresa para lhe evitar prejuízo ou proporcionar proveito;

c) em viagem a serviço da empresa, inclusive para estudo quando financiada por esta dentro de seus planos para melhor capacitação da mão-deobra, independentemente do meio de locomoção utilizado, inclusive veículo de propriedade do segurado;

d) no percurso da residência para o local de trabalho ou deste para aquela, qualquer que seja o meio de locomoção, inclusive veículo de propriedade do segurado."

Dentre as hipóteses mencionadas no dispositivo legal citado acima, merece destaque o acidente assim considerado em razão da concausa, diante de sua complexidade e da maior frequência com que é objeto de controvérsias no âmbito judicial.

De acordo com Sobrinho (2012), a concausa é uma circunstância ou causa paralela, que embora independente da causa principal, atua em conjunto com essa para a eficácia do resultado do evento danoso.

A definição mais completa acerca da idéia de concausalidade foi elaborada por Russomano:

"A causa propriamente dita, a causa originária, a causa traumática, como dizem os peritos, gera determinados efeitos, mas não são, por sua vez, resultantes da causa traumática. São concorrentes e, não decorrentes.

A exemplificação dada por Afrânio Peixoto, nesse sentido, elucida o problema: o indivíduo que sofre de hemofilia recebe ferimento e morre esvaído em sangue.

Outro indivíduo é atingido, no braço, por objeto cortante, que secciona a artéria umeral, ocasionando-lhe a morte, também por hemorragia.

No primeiro caso, a hemofilia - como uma situação anterior ao acidente - veio contribuir para que o ferimento - a causa traumática - determinasse a morte da vítima. A hemofilia, na hipótese, é concausa.

No segundo caso, a hemorragia era consequência natural e previsível do próprio acidente. Não houve concurso de nenhum outro fator e, portanto, não há como falar em concausa (Afrânio Peixoto, op. Cit. P. 226).” (Russomano, 1981: 405-406) (Castro, 2011: 575)

Nesse diapasão, é de se concluir que nem sempre o acidente se apresenta como causa única e exclusiva da lesão ou doença, pois poder haver a conjugação de outros fatores (concausa).

Isto porque, na ocorrência de acidente do trabalho podem concorrer uma causa relacionada ao trabalho e outras tantas sem qualquer relação com a atividade profissional. Nesse prisma, conclui-se que a concausalidade é circunstância independente do acidente e que a causa deste é somada para se chegar ao resultado danoso final. 
Existem também os acidentes de trabalho por equiparação ocorridos no local e no horário de trabalho, os quais estão presentes no rol taxativo das alíneas dos incisos $I I$ e $I V$, do art. 21, da Lei n. 8.213/91. Ressalta-se que tais casos são de difícil ocorrência na prática, mas não impossíveis.

A principal espécie dos acidentes de trabalho por equiparação é o acidente de trajeto (ou in itinere).

Segundo Sobrinho (2012), o acidente de trajeto pode ser conceituado como aquele que ocorre no percurso da residência para o local de trabalho ou deste para aquela, ou ainda para o local em que habitualmente o segurado se desloca após o término da jornada de trabalho.

2.5. Reconhecimento dos Benefícios por Incapacidade na espécie acidentária pelo Poder Judiciário de Santa Catarina

Conforme explanado anteriormente, os benefícios por incapacidade Aposentadoria por Invalidez e Auxílio-doença possuem duas espécies, dentre elas, a acidentária, que por sua vez, é caracterizada quando há correlação entre as patologias incapacitantes acometidas pelo segurado e a atividade profissional desempenhada por ele.

Para fins de comprovação dessa relação entre doenças incapacitantes e atividade laboral se faz necessário caracterizar o nexo de causalidade entre um e outro. Isto porque, o nexo causal constitui a relação de causa e efeito entre o evento danoso e o resultado.

Ocorre que, na prática, a perícia médica do Instituto Nacional do Seguro Social - INSS geralmente não reconhece o benefício por incapacidade na espécie acidentária, razão pela qual os segurados acabam tendo de procurar o Poder Judiciário, a fim de que o benefício por incapacidade tenha sua espécie convertida para a benesse acidentária.

Nesse diapasão, o principal meio de prova utilizado para caracterização do acidente do trabalho é a Comunicação de Acidente de Trabalha - CAT, a qual foi criada exatamente para noticiar o evento.

De acordo com Cabral (2014), a CAT nada mais é do que o documento capaz de formalizar a notificação ao INSS (instituição competente para homologar tal notificação) de um acidente do trabalho.

Castro E Lazzari (2011) ensinam que a CAT ao INSS é feita por formulário próprio, e constitui obrigação da empresa, no prazo de até o primeiro dia útil após a ocorrência, e, em caso de falecimento, de imediato, à autoridade policial competente, sob pena de multa variável entre os limites mínimo e máximo do salário de contribuição, a ser aplicada pela fiscalização do INSS.

Dessa forma, destaca-se que a existência da CAT é fundamental para que o benefício por incapacidade seja concedido na espécie acidentária, justamente porque tal documento tem o condão de exprimir/noticiar o acidente de trabalho.

Nesse contexto, colhe-se da jurisprudência catarinense:

APELAÇÃO CÍVEL - REEXAME NECESSÁRIO - ACIDENTÁRIO PLEITO DE CONVERSÃO DO AUXÍLIO-DOENÇA PREVIDENCIÁRIO EM SEU CONGÊNERE ACIDENTÁRIO - SEGURADO PORTADOR DE SEQUELAS POR TRAUMATISMO CRANIANO, E FRATURAS NO MAXILAR E MANDÍBULA - NEXO CAUSAL ENTRE A LESÃO E O EXERCÍCIO DAS ATIVIDADES LABORATIVAS DO OBREIRO SUFICIENTEMENTE DEMONSTRADO - JUNTADA DE 


\section{COMUNICAÇÃO DE ACIDENTE DO TRABALHO (CAT) - DIREITO RECONHECIDO - REEXAME DESPROVIDO.}

"Demonstrada, a partir da CAT, que as lesões que motivaram a implantacão do benefício têm origem no ambiente de trabalho, correta a conversão do auxílio-doença previdenciário para seu congênere acidentário."(Apelação Cível n. 2012.037522-7, de Timbó, rel. Des. Pedro Manoel Abreu, j. 04-05-2013)

TERMO FINAL DA BENESSE FIXADO NA SENTENÇA (05-02-2013) IMPOSSIBILIDADE - BENEFÍCIO PRORROGADO NA ESFERA ADMINISTRATIVA ATÉ 05-02-2015 - MANUTENÇÃO DO AUXÍLIODOENÇA ACIDENTÁRIO ATÉ A REABILITAÇÃO PROFISSIONAL DO SEGURADO, OU CASO SEJA CONSIDERADO, POR MEIO DE PERÍCIA MÉDICA, NÃO RECUPERÁVEL, FOR APOSENTADO POR INVALIDEZ INTELIGÊNCIA DO ART. 62 DA LEI N. 8.213/1991 - RECURSO DO AUTOR PROVIDO.

(TJSC, Segunda Câmara de Direito Público, Apelação Cível nº 2013.062983-1, de Lages. Rel. Des. Cid Goulart, j. em 01-04-2014) (Grifei).

Do julgado cuja ementa foi transcrita acima, infere-se que para fins de conversão da espécie do auxílio-doença para sua benesse acidentária, levou-se em consideração pelos magistrados julgadores a existência de Comunicação de Acidente do Trabalho - CAT, a qual foi fundamental para demonstrar que as lesões incapacitantes do segurado tiveram origem no ambiente profissional.

Ademais, colhe-se do acórdão proferido nos autos da Apelação Cível n. 2013.037522-7, da relatoria do Desembargador Pedro Manoel Abreu (julgada em 04-05-2013):

"VOTO

Aduz o apelante que não há qualquer prova nos autos acerca da origem das lesões que, conforme argumenta, ocorreram na residência do segurado, não justificando a concessão de benefício acidentário.

Entretanto, uma simples análise dos autos permite diversa conclusão.

Junto com a inicial a autora apresentou Comunicação de Acidente de Trabalho emitida pela empresa Viação Waltur LTDA, na qual é informada a ocorrência do infortúnio laboral em 31.3.2007, descrito como "traumatismo do ombro direito", após esforco ao empurrar bujão de gás.

As lesões são condizentes com aquelas encontradas pelas perícias do próprio INSS, fls. 17 e seguintes, e que motivaram a concessão do benefício em 16.4.2007, 15 dias após o acidente, conforme prevê o caput do art. 59 da Lei n. 8.213/91.

Não há provas a afastar a presuncão de veracidade da CAT emitida pelo empregador, até porque a própria autarquia reconheceu a procedência do pedido ao efetuar proposta de acordo (fl. 48).

Desse modo, visualizada a origem da lesão como sendo no ambiente de trabalho, escorreita a conversão do auxílio-doenca previdenciário em seu congênere acidentário." (Grifei).

No mesmo sentido do primeiro julgado, este destaca a existência de CAT emitida pela empresa empregadora informando a ocorrência do acidente laboral, cujas sequelas foram devidamente identificadas pela perícia médica do INSS. Assim, restou comprovado o nexo causal entre a origem da patologia incapacitante e a atividade profissional, razão pela qual o 
benefício foi convertido para sua benesse acidentária.

Outrossim, nos casos concretos em que a perícia médica judicial ateste a origem da incapacidade laboral como multifatorial, por ter sido emitida a respectiva CAT, aplica-se o princípio do in dubio pro misero e, dessa forma, o benefício por incapacidade é devido na espécie acidentária, senão vejamos:

REEXAME NECESSÁRIO E APELAÇÃO CÍVEL. PREVIDENCIÁRIO. PRELIMINAR DE FALTA DE INTERESSE DE AGIR AFASTADA. INCAPACIDADE TEMPORÁRIA. DEPRESSÃO. RECEBIMENTO DE AUXÍLIO-DOENCCA PREVIDENCIÁRIO. CONVERSÃO DO BENEFÍCIO NO SEU HOMÔNIMO ACIDENTÁRIO. POSSIBILIDADE. PERÍCIA

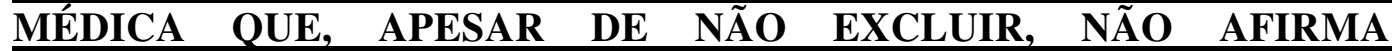

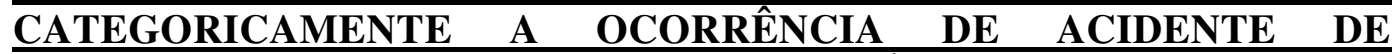
TRABALHO E NEXO DE CAUSALIDADE. DÚVIDA QUE SE RESOLVE EM FAVOR DO SEGURADO. APRESENTACÃO DO COMUNICACÃO DE ACIDENTE DE TRABALHO (CAT). OBSERVÂNCIA DO PRINCÍPIO DO IN DUBIO PRO MISERO. REMESSA E APELO DESPROVIDO.

(TJSC, Quarta Câmara de Direito Público, Apelação Cível no 2013.030074-2, da Capital. Rel. Des. José Volpato de Souza, j. em 15-08-2013). (Grifei). E ainda:

PREVIDENCIÁRIO. AUXÍLIO-ACIDENTE. HÉRNIA. PERÍCIA MÉDICA QUE, APESAR DE NÃO EXCLUIR, NÃO AFIRMA CATEGORICAMENTE A OCORRÊNCIA DE ACIDENTE DE TRABALHO E NEXO DE CAUSALIDADE. DÚVIDA QUE SE RESOLVE EM FAVOR DO SEGURADO. OBSERVÂNCIA DO PRINCÍPIO DO IN DUBIO PRO MISERO.

Quando o laudo pericial, sem afirmar categoricamente a existência de acidente de trabalho e o respectivo nexo de causalidade, não exclui tal possibilidade, estar-se-á diante de uma dúvida razoável que deve ser resolvida em favor do segurado, em observância do princípio do in dubio pro misero, devendo, por consequência, se considerar comprovados tais requisitos. [...] (TJSC, Segunda Câmara de Direito Público, Apelação Cível n. 2013.021276-0, de Palhoça. Rel. Des. Francisco de Oliveira Neto, julgado em 0907-2013) (Grifei).

Assim, interessante notar que havendo dúvida sobre a existência ou não de nexo causal ou etiológico entre a atividade laboral e a doença que acomete o obreiro, há diversos julgados no sentido de que o nexo causal é presumido, mediante aplicação do princípio in dubio pro misero, como enfatizado anteriormente.

Nesse contexto, diante dos julgados colacionados acima, é de se concluir que a jurisprudência catarinense leva em consideração a emissão da Comunicação de Acidente do Trabalho - CAT para fins de reconhecimento do nexo de causalidade entre as enfermidades incapacitantes e a atividade profissional do segurado da Previdência Social.

Logo, perante o judiciário de Santa Catarina, para a concessão dos benefícios por incapacidade na espécie acidentária é de suma importância que tenha sido emitida a respectiva CAT, a qual possui presunção de veracidade quanto à ocorrência do acidente de trabalho.

Além disso, ainda que a prova técnica judicial tenha concluído que as doenças acometidas pelos segurados não sejam de origem laboral, em havendo emissão de CAT, pressupõe-se o nexo causal entre as enfermidades e o trabalho, com fulcro no princípio do in 
dubio pro misero, determinando-se a concessão do benefício na benesse trabalhista.

Dessa forma, sob a ótica da proteção social do trabalhador, na ocorrência de acidente de trabalho, importante que o obreiro busque a emissão da Comunicação de Acidente do Trabalho - CAT, via empregador ou até mesmo pela entidade sindical que representa a categoria profissional, justamente porque a existência de tal documento é fundamental para a caracterização do infortúnio laboral, nos termos da jurisprudência catarinense.

\section{CONCLUS $\tilde{A O}$}

A preocupação do legislador em assegurar aos cidadãos o direito à seguridade social está disciplinada em várias normas, dentre elas, a Carta Magna.

Nesse diapasão, o Estado possui dentre suas funções a de proteger os indivíduos em relação aos eventos que lhes causam dificuldade ou impossibilidade de subsistência por conta própria.

Dessa forma, a Previdência Social tem por objetivo garantir a prestação correspondente ao fato ocorrido com o segurado, mediante concessão do benefício previdenciário por incapacidade nos casos em que o trabalhador esteja incapacitado para o exercício de sua atividade profissional.

Entretanto, na ocorrência de acidente de trabalho, na maioria das vezes, o benefício por incapacidade não é concedido em sua espécie acidentária pelo Instituto Nacional do Seguro Social, ainda que exista Comunicação de Acidente do Trabalho - CAT, documento capaz de traduzir a correlação entre as patologias incapacitantes acometidas pelo segurado e a atividade profissional desempenhada por ele.

Assim, é que o segurado acaba tendo de acionar o Poder Judiciário para fins de garantir, por meio de tutela jurisdicional, a concessão do benefício por incapacidade na benesse acidentária.

Vimos que a jurisprudência catarinense está pacificada no sentido de que o auxíliodoença deve ser concedido na espécie acidentária nos casos em que há emissão de Comunicação de Acidente de Trabalho, tendo em vista que tal documento é fundamental para demonstrar que as lesões incapacitantes dos segurados têm origem no ambiente profissional.

Outrossim, nos casos concretos em que a perícia médica judicial ateste a origem da incapacidade laboral como multifatorial, por ter sido emitida a respectiva CAT, aplica-se o princípio do in dubio pro misero e, dessa forma, o benefício por incapacidade é devido na espécie acidentária.

Nesse diapasão, destaca-se que em havendo dúvida sobre a existência ou não de nexo causal ou etiológico entre a atividade laboral e a doença que acomete o obreiro, uma vez emitida a Comunicação de Acidente de Trabalho, a jurisprudência indica que o nexo causal é presumido, mediante aplicação do princípio in dubio pro misero.

Assim, diante dos julgados colacionados acima, é de se concluir que a jurisprudência catarinense leva em consideração a emissão da Comunicação de Acidente do Trabalho - CAT para fins de reconhecimento do nexo de causalidade entre as enfermidades incapacitantes e a atividade profissional do segurado da Previdência Social.

Logo, perante o judiciário de Santa Catarina, para a concessão dos benefícios por incapacidade na espécie acidentária é de suma importância que tenha sido emitida a respectiva CAT, a qual possui presunção de veracidade quanto à ocorrência do acidente de trabalho.

Além disso, ainda que a prova técnica judicial tenha concluído que as doenças acometidas pelos segurados não sejam de origem laboral, em havendo emissão de CAT, 
pressupõe-se o nexo causal entre as enfermidades e o trabalho, com fulcro no princípio do in dubio pro misero, determinando-se a concessão do benefício na benesse trabalhista.

Dessa forma, sob a ótica da proteção social do trabalhador, na ocorrência de acidente de trabalho, importante que o obreiro busque a emissão da Comunicação de Acidente do Trabalho - CAT, via empregador ou até mesmo pela entidade sindical que representa a categoria profissional, justamente porque a existência de tal documento é fundamental para a caracterização do infortúnio laboral, nos termos da jurisprudência catarinense.

\section{REFERENNCLAS}

. Decreto $n^{\circ}$. 3.048, de 06 de maio de 1999. Aprova o Regulamento da Previdência Social, e dá outras providências. Disponível em: $<$ http://www.planalto.gov.br/ccivil_03/decreto/d3048.htm>. Acesso em: 23 de Dezembro de 2014.

Lei $\mathrm{n}^{\circ}$. 8.213, de 24 de julho de 1991 - Lei Ordinária. Disponível em: $<$ http://www.planalto.gov.br/ccivil_03/leis/L8213cons.htm>. Acesso em: 23 de Dezembro de 2014.

CASTRO, Carlos Alberto Pereira de; LAZZARI, João Batista, (2011). Manual de Direito Previdenciário. 13 . ed. São Paulo: Conceito Editorial.

SILVA, José Antônio Ribeiro de Oliveira. Acidente do trabalho: Responsabilidade Objetiva do Empregador. $3^{\mathrm{a}}$ ed. São Paulo: LTr.

PACHECO, Iara Alves Cordeiro, (2014). Acidente do Trabalho: causas e consequências da sonegação da CAT. São Paulo: LTr.

CABRAL, Lenz Alberto Alves, (2014). Abre a CAT?: nexo causal no acidente do trabalho/doença ocupacional. $4^{\text {a }}$ ed. São Paulo: LTr.

GIMENES, Mara Aparecida, (2014). Incapacidade laboral e benefício por auxílio-doença no INSS. São Paulo: LTr.

SOBRINHO, Zéu Palmeira, (2012). Acidente do Trabalho: críticas e tendências. São Paulo: LTr.

OLIVEIRA, Sebastião Geraldo de. (2006). Indenizações por Acidente do Trabalho ou Doença Ocupacional. São Paulo: LTr.

IBRAHIM, Fábio Zambite, (2008). Curso de Direito Previdenciário. 13ª . ed. Rio de Janeiro: Impetus.

VIANNA, Cláudia Salles Vilela, (2010). A relação de emprego e os impactos decorrentes dos benefícios previdenciários. $2^{a}$. ed. São Paulo: LTr.

ROCHA, Daniel Machado da Rocha; SAVARIS, José Antônio, (2006). Curso de Especialização em Direito Previdenciário - Volume 2 - Benefícios da Seguridade Social. Curitiba: Juruá.

ROCHA, Daniel Machado da Rocha; SAVARIS, José Antônio, (2006). Curso de Especialização em Direito Previdenciário - Volume 1 - Direito Previdenciário Constitucional. Curitiba: Juruá. 